\title{
STUDI PERILAKU HARIAN DAN KESEJAHTERAAN MONYET HITAM SULAWESI (Macaca nigra Desmarest, 1822) DI PUSAT PRIMATA SCHMUTZER
}

\author{
Study of Daily Behavior and Animal Welfare Celebes Black Macaque in Schmutzer Primate \\ Center
}

Desy Octavia ${ }^{1}$, Ratna Komala ${ }^{1}$, Atin Supiyani ${ }^{1 *}$

Program Studi Biologi FMIPA Universitas Negeri Jakarta

*Corresponding Email: atinsupiyani78@gmail.com

\begin{abstract}
ABSTRAK
Monyet hitam sulawesi merupakan primata endemik yang hampir punah. Konservasi ex situ monyet hitam sulawesi harus memperhatikan segala aspek yang berhubungan dengan kehidupan hewan tersebut, termasuk aspek perilaku dan kesajahteraan hewan. Penelitian ini bertujuan untuk mengetahui perilaku harian monyet hitam sulawesi berdasarkan jenis kelamin dan umur, serta tingkat kesejahteraannya di Pusat Primata Schmutzer (PPS). Metode yang digunakan dalam penelitian ini adalah metode deskriptif dengan teknik observasi. Analisis data perilaku harian monyet hitam sulawesi berdasarkan jenis kelamin dan umur dilakukan dengan uji Mann- Whitney, sedangkan analisis data tingkat kesejahteraan hewan dilakukan secara deskriptif. Hasil penelitian menunjukan bahwa terdapat perbedaan perilaku harian monyet hitam sulawesi berdasarkan jenis kelamin, yaitu pada perilaku bergerak, mencari makan, istirahat, dan sosial. Hasil penelitian juga menunjukan terdapat perbedaan perilaku harian monyet hitam sulawesi berdasarkan umur, yaitu pada perilaku bergerak, istirahat, dan sosial. Berdasarkan hasil analisis, tingkat kesejahteraan monyet hitam sulawesi di PPS termasuk dalam kriteria baik.
\end{abstract}

Kata Kunci: kesejahteraan hewan, konservasi ex situ, Macaca nigra, perilaku, PPS

\section{PENDAHULUAN}

Monyet hitam sulawesi (Macaca nigra Desmarest, 1822) merupakan salah satu dari tujuh primata endemik Sulawesi.Monyet hitam Sulawesi merupakan hewan diurnal (Supriatna dan Wahyono, 2000). Menurut Saroyo et.al (2006), perilaku harian monyet hitam sulawesi di CA Tangkoko Batuangus meliputi 34,5\% makan dan mencari makan, 18,7\% bergerak, 28,6\% istirahat dan 18,1\% sosial. O’Brien dan Kinnaird (1997) menambahkan bawa perilaku harian monyet hitam sulawesi dipengaruhi oleh jenis kelamin dan umur.

Populasi monyet hitam sulawesi dari tahun ke tahun terus mengalami penurunan (Kyes et al., 2013). Menurut IUCN Red list 2008, status monyet hitam sulawesi telah ditingkatkan statusnya menjadi Critically Endangered (Supriatna dan Andayani, 2008). Salah satu langkah yang dapat diambil untuk menghindari kepunahan monyet 
hitam sulawesi ialah dengan melakukan upaya konservasi ex situ (Indrawan et al., 2007). Salah satu lembaga yang melakukan upaya konservasi satwa secara ex situ terhadap monyet hitam sulawesi ialah Pusat Primata Schmutzer (PPS)

Pengelolaan penangkaran monyet hitam sulawesi harus memperhatikan segala aspek yang berhubungan dengan kehidupan hewan tersebut, termasuk aspek perilaku dan kesajahteraan hewan. Menurut Susanto (2000), ilmu perilaku merupakan dasar utama dalam pengelolaan hewan liar. Alikodra (2002) menambahkan bahwa keberhasilan usaha penangkaran dari suatu spesies sangat didukung oleh pengetahuan dari perilaku hewan tersebut.

Kesejahteraan hewan merupakan indikator tentang gambaran praktek pengelolaan yang dilakukan suatu lembaga konservasi (Anggraini, 2015). Tingkat kesejahteraan hewan ini dapat diketahui dengan adanya penilain lembaga konservasi. Tujuan penilaian lembaga konservasi ialah untuk meingkatkan kesejahteraan hewan (PHKA, 2011).

Menurut Farm Animal Welfare Council (FAWC) (2009), terdapat lima kebebasan hewan yang mencerminkan kesejahteraan hewan, yaitu bebas dari rasa lapar dan haus, bebas dari rasa nyeri, luka, dan sakit, bebas dari rasa takut dan tertekan, bebas dari rasa tidak nyaman, dan bebas untuk mengekspresikan perilaku normalnya. Pengabaian lima faktor kebebasan pada hewan liar dalam kurungan akan mengakibatkan peningkatan perilaku abnormal atau perilaku stereotipe pada hewan (ISAW, 2013). Melfi dan Feitsner (2002) menambahkan bahwa perilaku natural hewan seperti di alam pada hewan yang ditangkarkan mencerminkan kesejahteraan hewan yang baik. Oleh karena itu, penelitian mengenai perilaku harian dan kesejahteraan monyet hitam sulawesi di PPS penting dilakukan untuk dapat menunjang upaya konservasi ex situ monyet hitam sulawesi.

\section{MANFAAT}

Hasil penelitian dapat memberikan informasi mengenai perilaku harian dan kesejahteraan monyet hitam sulawesi di PPS. Informasi ini diharapkan dapat dimanfaatkan sebagai dasar pertimbangan dalam penyusunan kebijakan upaya konservasi monyet hitam sulawesi secara ex situ di penangkaran.

\section{HIPOTESIS PENELITIAN}

Hipotesis penelitian ini adalah:

1. Terdapat perbedaan perilaku harian monyet hitam sulawesi berdasarkan Jenis kelamin

2. Terdapat perbedaan perilaku harian monyet hitam sulawesi berdasarkan umur

3. Kesejahteraan monyet hitam sulawesi termasuk kriteria baik

\section{METODOLOGI PENELITIAN}

\section{WAKTU DAN TEMPAT}

Penelitian ini dilaksanakan \pm selama 2 bulan, yaitu pada bulan Mei-Juni 2016 di Pusat Primata Schmutzer.

\section{BAHAN DAN ALAT}

Objek yang diamati adalah monyet hitam sulawesi yang ada di kandang penangkaran PPS, yang terdiri dari 2 jantan dewasa, 3 betina dewasa dan 2 anak. Alat penelitian yang digunakan diantaranya adalah teropong binokuler, weather meter, kamera digital, jam digital dan tabulasi data. 


\section{METODE PENELITIAN}

Metode yang digunakan dalam penelitian ini adalah metode deskriptif dengan teknik observasi.

PROSEDUR KERJA

Mengambil data perilaku harian

Pengambilan data perilaku harian dilakukan selama 7 jam dalam satu hari, yaitu dimulai pukul 08.00-12.00 WIB dan pukul 13.00-16.00 WIB. Pengamatan untuk betina dewasa, jantan dewasa dan anak masing-masing dilakukan sebanyak 20 hari.

Metode yang digunakan ialah Focal Animal Sampling (Martin dan Bateson, 1999), yaitu mengamati dan mencatat perilaku satu individu selama periode waktu tertentu. Pencatatan perilaku harian dilakukan dengan instantineus recording dengan interval waktu 1 menit.

\section{Mengamati Pengelolaan Monyet Hitam Sulawesi}

Aspek pengelolaan yang diamati meliputi: 1) pakan, yaitu meliputi jenis pakan yang diberikan, cara pemberian pakan, waktu pemberian pakan, komposisi pakan yang diberikan dan tempat penyimpanan suplai pakan, 2) perkandangan, yaitu meliputi jenis kandang, jumlah kandang, bentuk kandang, permukaan lantai kandang, pagar pembatas, material penyusun kandang, fasilitas pendukung dalam kandang dan kebersihan kandang, 3) perawatan kesehatan dan penyakit, yaitu meliputi jenis penyakit yang biasa menyerang, gejala, tidakan penanggulangan, tindakan pencegahan, suplai dan penyimpanan obat-obatan, dan fasilitas perawatan bagi hewan yang sakit.

\section{Menilai Kesejahteraan Monyet Hitam Sulawesi di PPS}

Penilaian tingkat kesejahteraan hewan dilakukan berdasarkan daftar isian yang diacu dalam Peraturan Direktur Jenderal Perlindungan Hutan dan Konservasi Alam (PHKA) nomor P.6/IV-SET/2011 tentang Pedoman Penilaian Lembaga Konservasi

$$
\text { Persentase perilaku harian }=\frac{\text { jumlah perilaku X }}{\text { jumlah seluruh perilaku }} \times 100 \%
$$

\section{TEKNIK ANALISIS DATA}

Data frekuensi perilaku harian yang diperoleh dihitung dengan rumus Martin dan Bateson (1993) sebagai berikut:

Uji statistik U Mann Whitney dilakukan untuk mengetahui apakah terdapat perbedaan frekuensi perilaku harian antara monyet hitam sulawesi berdasarkan jenis kelamin dan umur.

$$
\text { Penilaian kesejahteraan hewan }=\frac{\text { skor yang diperoleh }}{\text { skor maksimum }} \times 100 \%
$$

Data skor tingkat kesejahteraan hewan sesuai Peraturan Direktur Jendral PHKA No.6 Tahun 2011 dikelompokan dalam lima kriteria penilaian, yaitu: 1 = buruk, 2 = kurang, $3=$ cukup, $4=$ baik dan $5=$ sangat baik. Hasil penilaian kesejahteraan hewan dapat dihitung dengan rumus sebagi berikut:

Persentase penilaian kesejahteraan monyet hitam sulawesi secara keseluruhan (berdasarkan lima aspek kebebasan) didapat dari rata-rata penilaian kelima aspek kebebasan tersebut. Kemudian persentase penilaian kesejahteraan hewan yang diperoleh diklasifikasikan berdasarkan empat kriteria kesejahteraan hewan sesuai 
Tabel 1. Kriteria Penilaian Kesejahteraan Hewan Berdasarkan Peraturan Direktur Jendral PHKA No.6 Tahun 2011

\begin{tabular}{lll}
\hline No. & Kriteria Penilaian & Persentase Penilaian \\
\hline 1. & Kurang & $<60 \%$ \\
2. & Cukup & $60-69.99 \%$ \\
3. & Baik & $70-79,99 \%$ \\
4. & Sangat baik & $80-100 \%$ \\
\hline
\end{tabular}

Peraturan Direktur Jendral PHKA No.6 Tahun 2011 (Tabel 1). Analisis yang dilakukan untuk kesejahteraan monyet hitam sulawesi di PPS ialah analisis deskriptif.

\section{HASIL DAN PEMBAHASAN}

\section{PERILAKU HARIAN MONYET HITAM SULAWESI BERDASARKAN JENIS KELAMIN}

Berdasarkan hasil pengamatan, frekuensi perilaku harian terbanyak moyet hitam sulawesi betina dan jantan ialah perilaku istirahat, diikuti dengan perilaku makan, bergerak, sosial, dan mencari makan. Hasil pengamatan perilaku harian monyet hitam sulawesi berdasarkan jenis kelamin dapat dilihat pada Gambar 1.

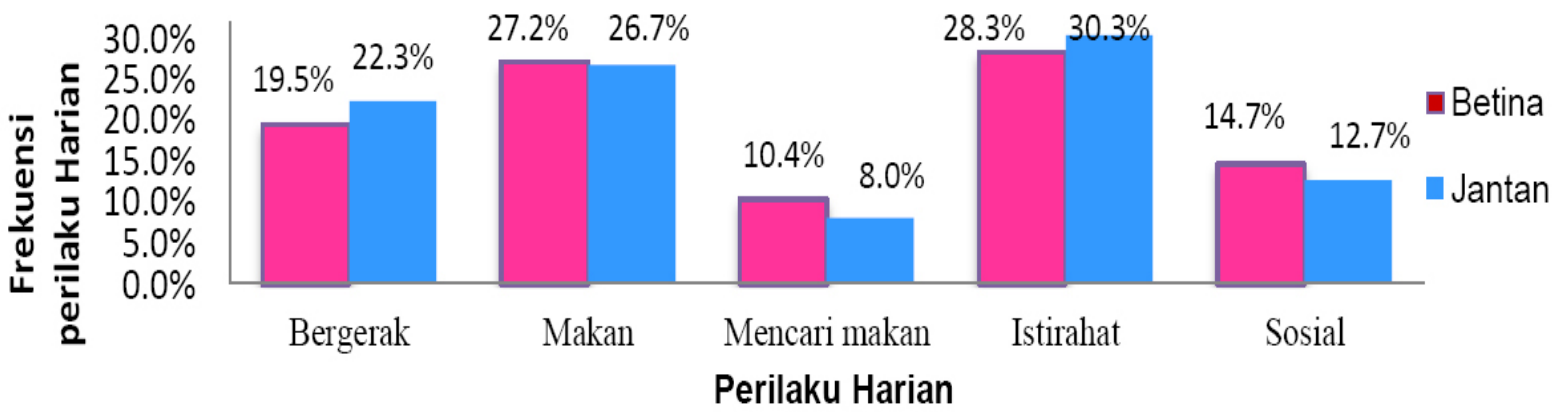

Gambar 1. Frekuensi Perilaku harian Monyet Hitam Sulawesi Berdasarkan Jenis Kelamin

Berdasarkan hasil uji statistik, perilaku bergerak $(p=0,010)$, mencari makan $(p=0,000)$, istirahat $(p=0,002)$, dan sosial $(\mathrm{p}=0,002)$ monyet hitam sulawesi berdasarkan jenis kelamin berbeda nyata. Sedangkan perilaku makan monyet hitam sulawesi berdasarkan jenis kelamin tidak berbeda nyata, dengan p-value sebesar 0,341.

\section{Perilaku Bergerak}

Frekuensi perilaku bergerak jantan lebih banyak dibandingkan frekuensi perilaku bergerak betina, hal ini diduga karena jantan butuh banyak bergerak untuk mengawasi kelompoknya. Menurut Reed et al. (1997) dalam O’brien dan Kinnaird (1997) peningkatan perilaku bergerak pada jantan dilakukan untuk penjagaan jantan terhadap kelompoknya.

Jantan lebih aktif bergerak juga diduga karena Basal Metabolic Rate (BMR) jantan yang lebih tinggi dibandingkan betina. Menurut Lazzer et al. (2010) jenis kelamin mempengaruhi BMR, jantan memiliki BMR lebih tinggi dibandingkan betina. Biro dan Stamps (2010) menambahkan bahwa BMR dapat berpengaruh terhadap perilaku karena berhubungan dengan energy expenditure untuk proses fisiologis yang menghasilkan perilaku.

Perilaku bergerak pada monyet hitam sulawesi betina dan jantan di PPS didominasi dengan berjalan dengan empat kaki (walking quadropedally). Hal ini sesuai dengan Supriatna dan Wahyono (2000) yang menyatakan bahwa 
pergerakan monyet hitam sulawesi ialah dengan keempat anggota geraknya (quadropedal). Penggunaan keempat anggota gerak ini dikarenakan monyet hitam sulawesi merupakan hewan semiterrestrial yang yang menggunakan lebih dari 60\% waktunya untuk beristirahat dan bergerak di atas tanah (Kilner, 2001)

Jantan lebih cenderung menggunakan tipe pergerakan memanjat, meloncat dan melompat dari pada betina. Jenis pergerakan tersebut diduga dilakukan oleh jantan untuk patroli dan pengawasan terhadap daerah teritori. Mondoringin et al. (2016) menambahkan bahwa jantan bertugas memimpin suatu kelompok dengan mendominasi anggota lainnya, sehingga banyak melakukan pergerakan dan perilaku agresif untuk melindungi kelompoknya.

\section{Perilaku Makan}

Frekuensi perilaku makan monyet hitam sulawesi betina dan jantan tidak berbeda, hal ini diduga karena berkurangnya efek dominansi terhadap akses pakan oleh pemberian pakan yang dilakukan secara tersebar di PPS. Menurut Riptianingsih (2011), pemberian pakan dengan cara disebar di beberapa tempat merupakan salah satu strategi untuk mengurangi efek dominansi terhadap pakan.

Jenis pakan yang dominan dimakan oleh monyet hitam sulawesi baik betina maupun jantan adalah buah. Hal ini sesuai dengan teori yang menyatakan bahwa monyet hitam sulawesi merupakan pemakan buah (frugivorus) (Supriyatna dan Wahyono, 2000). Menurut Hakim (2010), konsumsi buah oleh monyet hitam sulawesi dapat mencapai $60-90 \%$ dari total konsumsi pakannya.

Monyet hitam sulawesi di PPS juga didapati memakan bagian tumbuhan lain, dan serangga. Bagian tumbuhan lain yang dikonsumsi monyet hitam sulawesi yaitu daun, biji, bunga, dan umbi, Serangga yang dikonsumsi oleh monyet hitam sulawesi di PPS ialah semut dan nyamuk. Pakan yang dikonsumsi oleh monyet hitam sulawesi ini sebagian besar merupakan pakan yang diberikan oleh pengelola, namun ada juga pakan yang dberasal dari pengayaan kandang dan sekitar kandang. Menurut Supriatna dan Wahyono (2000) jenis pakan selain buah yang dimakan oleh monyet hitam sulawesi ialah bagian tumbuhan seperti daun, pucuk, bunga, biji, dan umbi, serta memakan beberapa jenis invertebrata dan jamur. Namun monyet hitam sulawesi di PPS tidak ditemukan memakan jamur, hal ini karena jamur tidak diberikan oleh pengelola dan tidak ada disekitar kandang monyet hitam sulawesi.

Jantan lebih menyukai jenis pakan biji (kacang-kacangan), serangga, dan jenis pakan lainnya (telur rebus dan monkey chow) dibandingkan betina. Hal ini diduga karena jenis pakan tersebut lebih banyak mengandung protein dan lemak. Protein dan lemak berperan penting dalam pembentukan massa otot dan bobot tubuh. Menurut Supriyatna dan Wahyono (2000), monyet hitam sulawesi merupakan satwa dengan sexual dimorphism sehingga ukuran dari jantan bisa mencapai dua kali ukuran betina. Tubuh yang besar dan kuat juga diperlukan untuk menentukan kekuasaan atau dominansi monyet hitam sulawesi jantan.

\section{Perilaku Mencari Makan}

Frekuensi mencari makan betina lebih banyak dibandingkan jantan, hal ini diduga karena jantan mendapatkan akses prioritas dibandingkan dengan betina, sehingga jantan tidak perlu banyak mencari dan memilih pakan. Menurut

O”brien dan Kinnaird (1997), secara umum jantan memiliki akses prioritas terhadap pakan dan memiliki kualitas waktu makan yang lebih baik dibandingkan dengan betina.

\section{Perilaku Istirahat}

Frekuensi istirahat jantan lebih banyak dibandingkan dengan frekuensi istirahat betina, hal ini diduga karena jantan menyeimbangkan perilaku untuk menghemat penggunaan energi. Energy expenditure jantan sudah banyak dialokasikan untuk perilaku seperti bergerak dan mempertahankan wilayah, sehingga jantan harus menghemat 
pengeluaran energi dengan beristirahat lebih banyak.

lstirahat merupakan aktivitas monyet yang dapat dilakukan baik di pohon maupun di atas tanah. Selama istirahat, monyet duduk atau tiduran di atas tanah atau di cabang tanpa terlibat dalam aktivitas sosial (Saroyo et al., 2006). Perilaku istirahat jantan lebih didominasi oleh perilaku duduk dan diam. Hal ini diduga karena jantan harus selalu mengawasi kelompoknya, sehingga lebih memilih untuk beristirahat dengan duduk ataupun diam dibandingkan dengan berbaring bahkan tidur. Mondoringin et al. (2016) menambahkan bahwa perilaku jantan saat istirahat biasanya duduk diam sambil mengawasi daerah sekitar, terkadang sambil menutup mata atau dalam gaya mengantuk tetapi sebenarnya selalu dalam keadaan waspada.

\section{Perilaku Sosial}

Monyet hitam sulawesi betina lebih banyak terlibat dalam allogrooming untuk mendekatkan diri dengan anggota kelompok lainnya. Menurut Saroyo et al. (2006), perilaku allogrooming banyak dilakukan antarbetina dewasa, antara betina dan anak, dan antara betina dan jantan. Schino (2007) menambahkan bahwa Allogrooming ada hubungannya dengan aktivitas seksual karena tidak jarang pada saat jantan dewasa di grooming, jantan tersebut bereaksi dan terjadi perkawinan (coitus) setelah kegiatan tersebut atau sebaliknya setelah melakukan perkawinan mereka sering melakukan grooming.

Menurut Saroyo et al. (2006), perilaku seksual monyet hitam sulawesi dimulai dari jantan atau betina mendekati pasangannya, betina menunjukkan genital luarnya (hindquarter present), pemeriksaan genital oleh jantan (inspection), jantan menaiki tubuh betina (mounting), jantan memasukkan penis (intromission), gerakan jantan memasukkan dan mengeluarkan penis (thrusting), ejakulasi (ejaculation), dan jantan turun dari tubuh betina (dismounting). Namun, hasil pengamatan menunjukan bahwa tidak semua perilaku seksual sampai ke tahap kopulasi. Pada saat pengamatan ditemukan adanya perilaku betina yang memegang-megang penis jantan hingga mengeluarkan cairan atau ejakulasi, tetapi tidak melakukan kopulasi. Hal ini diduga karena betina tidak dalam masa esterus, sehingga jantan tidak mengawini betina. Suprihandini (1993) menemukan bahwa perilaku kawin dilakukan pada periode aktif dimana periode tersebut tidaklah teratur dan hanya terjadi pada waktu tertentu.

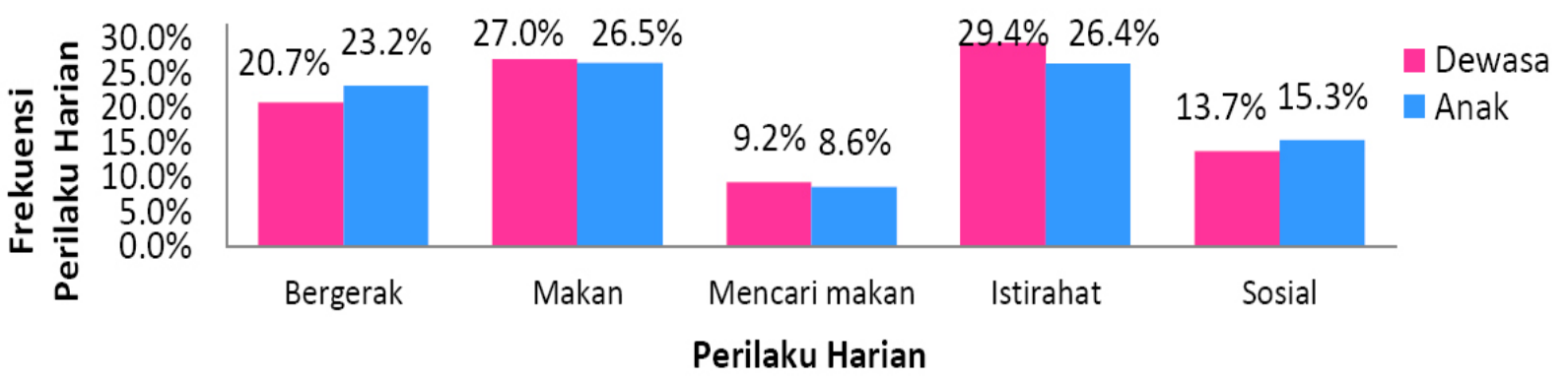

Gambar 2. Perbandingan Frekuensi Perilaku Harian Monyet Hitam Sulawesi Berdasarkan Umur

Perilaku agonistik lebih didominasi oleh jantan dibandingkan betina. Hal ini berkaitan dengan peran jantan dalam melindungi kelompoknya dari ancaman atu gangguan apapun, baik dari dalam maupun luar kelompok. Menurut Saroyo (2006), perilaku agonistik meliputi agonistik ringan maupun agonistik berat. Agonistik ringan antara lain mencakup mengancam dengan mata atau suara, membuka mulut dan menunjukkan taringnya, dan menggoyang-goyang ranting pohon. Agonistik berat mencakup mengusir individu lain, mencakar, atau menggigit, sehingga mengakibatkan luka terbuka. Perilaku agonistik monyet hitam sulawesi di PPS sering ditujukan kepada pengunjung maupun pekerja yang dirasa mengusik dengan membuka mulut dan menunjukan taring sampat 
memanjat dan mengoyak-ngoyak dinding kawat kandang. Hal ini sesuai dengan Watiniasih (2002) dan Tarigan (2009) yang menyatakan bahwa perilaku agresif banyak dilakukan oleh jantan dewasa.

Perilaku bermain pada dewasa lebih cenderung dilakukan oleh induk betina. Hal ini diduga karena induk betina lebih dekat dengan anak-anak dibandingkan jantan, sehingga betina lebih sehing terlibat bermain dengan anak dibandingkan jantan. Perilaku sosial parental care meliputi menyusui atau disusui, memeluk satu merangkul antar induk dan anak. Perilaku parental care ini hampir selalu dilakukan oleh induk betina dengan anak, hanya sesekali terlihat jantan merangkul individu anak. Menurut Saputra et al. (2012), perilaku memeluk anak hanya dilakukan oleh individu betina dewasa. Hal ini dilakukan sebagai bentuk perlindungan individu monyet betina dewasa terhadap anak-anaknya yang masih di bawah umur.

\section{PERILAKU HARIAN MONYET HITAM SULAWESI BERDASARKAN UMUR}

Berdasarkan hasil pengamatan, frekuensi perilaku harian terbanyak moyet hitam sulawesi dewasa dan anak ialah perilaku istirahat, diikuti dengan perilaku makan, bergerak, sosial, dan mencari makan. Hasil pengamatan perilaku harian monyet hitam sulawesi berdasarkan umur dapat dilihat pada Gambar 2.

Berdasarkan hasil uji statistik, perilaku bergerak $(p=0,002)$, istirahat $(p=0,000)$, dan sosial $(p=0,005)$ monyet hitam sulawesi berdasarkan jenis kelamin berbeda nyata. Sedangkan perilaku makan dan mencari makan monyet hitam sulawesi berdasarkan umur tidak berbeda nyata, dengan p-value sebesar 0,155 dan 0,150 .

\section{Perilaku Bergerak}

Frekuensi perilaku bergerak anak lebih banyak dibandingkan dengan frekuensi bergerak dewasa. Menurut Kartono et al. (2002), aktivitas bergerak banyak dilakukan oleh anak dalam rangka menjelajah dan bermain untuk mempelajari situasi wilayah jelajah dan teritorinya. Perilaku anak yang lebih aktif bergerak juga diduga karena Basal Metabolic Rate (BMR) anak lebih tinggi dibandingkan dewasa. Menurut Lazzer et al. (2010) umur juga dapat mempengaruhi BMR, anak-anak memiliki BMR lebih tinggi dibandingkan dewasa. Biro dan Stamps (2010) menambahkan bahwa BMR dapat berpengaruh terhadap perilaku karena berhubungan dengan energy expenditure untuk proses fisiologis yang menghasilkan perilaku.

Jenis pergerakan berjalan dengan empat kaki lebih dominan digunakan oleh monyet hitam sulawesi dewasa dibandingkan dengan anak. Sedangkan tipe pergerakan berlari, berjalan, bergelantungan, memanjat, meloncat, dan melompat cenderung dilakukan oleh anak dibandingkan dengan dewasa. Hal ini diduga karena anak lebih banyak melakukan pergerakan untuk bermain dan anak memiliki berat tubuh yang lebih ringan sehingga mudah untuk melakukan berbagai pergerakan seperti berjalan dengan dua kaki dan bergelantungan dibandingkan dengan dewasa.

\section{Perilaku Makan}

Frekuensi perilaku makan monyet hitam sulawesi dewasa dan anak tidak berbeda, hal ini diduga karena berkurangnya efek dominansi terhadap akses pakan oleh pemberian pakan yang dilakukan secara tersebar di PPS. Menurut Riptianingsih (2011), pemberian pakan dengan cara disebar di beberapa tempat merupakan salah satu strategi untuk mengurangi efek dominansi terhadap pakan.

Hasil pengamatan menunjukan bahwa anak cenderung lebih memilih memakan buah dibandingkan dewasa. Menurut O’brien dan Kinnaird (1997) anak lebih banyak mengkonsumsi buah dibandingkan kelas umur lainnya karena anak lebih aktif, sehingga membutuhkan lebih banyak kalori yang banyak terkandung dalam buah. 


\section{Perilaku Mencari Makan}

Berdasarkan hasil pengamatan, tidak terdapat perbedaan frekuensi perilaku mencari makan monyet hitam sulawesi dewasa dan anak. Anak sering ditemukan mengikuti betina dewasa saat betina dewasa mencari makan. Hal ini diduga sebagai proses pembelajaran pada anak untuk mendapatkan makanan, sehingga dapat bertahan hidup (survive).

Jenis perilaku mencari merupakan perilaku mencari pakan potensial yang banyak dilakukan pada lantai kandang yang sebagian besar ditumbuhi rumput. Berdasarkan hasil pengamatan, perilaku membawa pakan didominasi oleh anak. Hal ini diduga berkaitan dengan perilaku bermain dan bergerak yang tinggi pada anak. Anak sangat aktif bergerak dan bermain sehingga seringkali membawa makanannya sambil bermain.

\section{Perilaku Istirahat}

Frekuensi perilaku istirahat dewasa lebih banyak dibandingkan dengan frekuensi istirahat anak. Menurut Soendjoto et al. (2006), dewasa lebih banyak melakukan istirahat untuk menghemat pemakaian energi berlebih. Sedangkan pada anak waktu istirahat berkurang karena kebutuhan untuk kegiatan bergerak dan sosial.

lstirahat merupakan aktivitas monyet yang dapat dilakukan baik di pohon maupun di atas tanah. Selama istirahat, monyet duduk atau tiduran di atas tanah atau di cabang tanpa terlibat dalam aktivitas sosial (Saroyo et al., 2006). Perilaku istirahat lebih sedikit dijumpai pada anak diduga karena anak lebih sering bermain saat dewasa beristirahat dan cerderung tidak bisa diam. Anak dijumpai tidur saat dalam gendongan induknya setelah disusui. Perilaku autogrooming pada anak lebih dominan dibandingkan dengan dewasa karena anak jarang dibersihkan oleh individu lain kecuali oleh induk betina dan tidak ditemukan allogrooming sesama anak (Prayogo, 2006).

\section{Perilaku Sosial}

Frekuensi perilaku sosial anak dewasa lebih banyak dibandingkan dengan frekuensi sosial dewasa. Frekuensi perilaku allogrooming, dan agonistik didominasi oleh dewasa dibandingkan dengan anak. Anak lebih dominan untuk bermain dalam perilaku sosialnya. Perilaku seksual hanya ditemukan pada individu dewasa karena pada anak monyet hitam sulawesi belum mengalami kematangan reproduksi.

Perilaku bermain dapat dilakukan oleh seluruh kelompok-umur dan jenis kelamin meskipun frekuensi tertinggi terjadi pada kelompok anak. Biasanya tingkah laku bermain dilakukan di atas tanah atau pohon dengan

saling mengejar, bergulingan, atau saling menggigit yang bukan agresi. Prayogo (2006), menambahkan bahwa bermain merupakan salah satu sarana pembelajaran dan melatih gerak motorik pada anak lutung perak.

\section{KESEJAHTERAAN HEWAN}

Berdasarkan hasil pengamatan dan penilain kesejahteraan monyet hitam sulawesi di PPS, menunjukkan bahwa tingkat kesejahteraan monyet hitam sulawesi di PPS termasuk dalam kriteria baik. Nilai presentase kesejahteraan monyet hitam sulawesi yang diperoleh untuk kandang A sebesar 76,2\% dan untuk kandang B sebesar 76,3\%. Secara umum, kriteria ini memiliki arti bahwa pengelolaan monyet hitam sulawesi di PPS memperhatikan lima aspek kebebasan hewan.

Aspek Bebas dari Rasa Lapar dan Haus

Berdasarkan hasil pengamatan, dapat diketahui bahwa pakan yang diberikan untuk monyet hitam sulawesi 
di PPS dikirim dari gudang pakan pusat. Pakan tersebut dikirim untuk kebutuhan makan monyet hitam sulawesi selama dua hari. Hal ini dimaksudkan agar pakan yang diberikan selalu dalam kondisi segar. Pakan yang diberikan untuk monyet hitam sulawesi di PPS dibedakan menjadi dua kategori, yaitu pakan utama dan pakan tambahan. Pakan utama ialah pakan yang diberikan dalam jumlah besar dan disesuaikan dengan pakan alami dari monyet hitam sulawesi. Sedangkan pakan tambahan ialah pakan pelengkap yang diberikan untuk menunjang kebutuhan gizi monyet hitam sulawesi dalam jumlah kecil.

Tabel 13. Hasil Penilaian Kesejahteraan Monyet Hitam Sulawesi di PPS

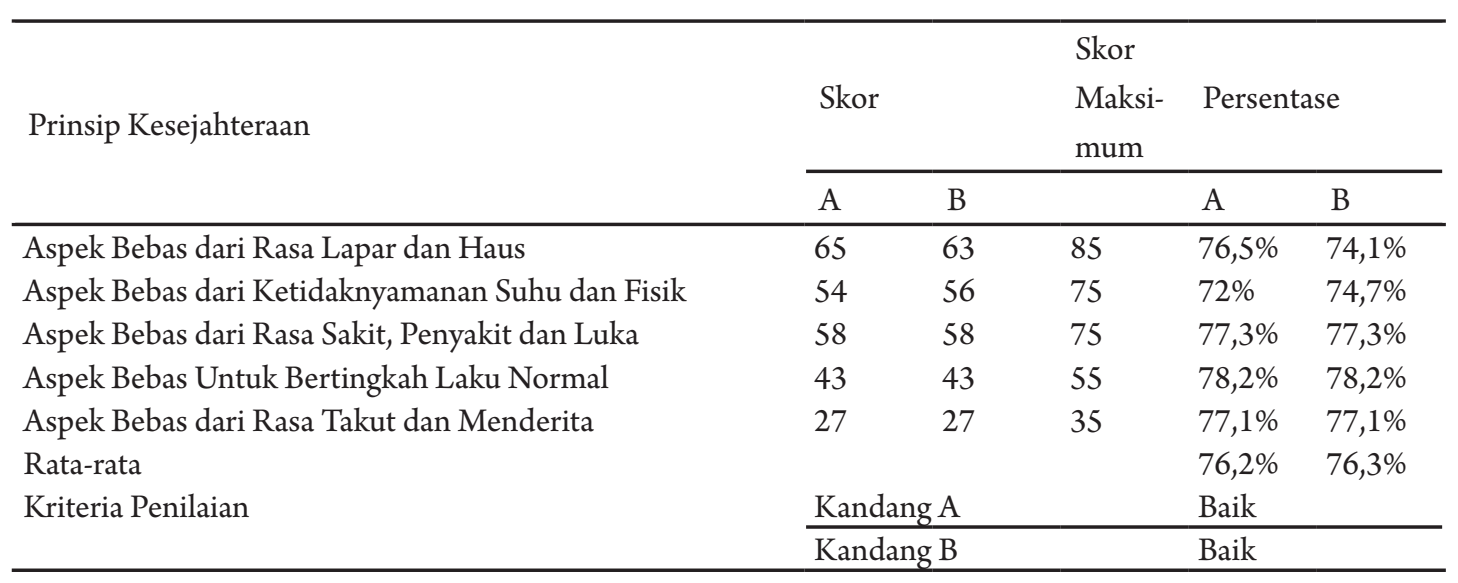

Keterangan

$A=$ Kandang $A$

$B=$ Kandang $B$

Komposisi pakan utama yang diberikan kepada monyet hitam sulawesi di PPS ialah 70\% buah-buahan, $10 \%$ dedaunan, $1 \%$ bunga, $10 \%$ biji-bijian dan $9 \%$ umbi-umbian. Jenis pakan buah-buahan memiliki persentase tertinggi dari pakan utama. Hal ini sudah sesuai dengan sifat monyet hitam sulawesi yang merupakan pemakan buah (frugivorous) dengan konsumsi buah sebanyak 60-90\% dari total konsumsi pakannya (Hakim, 2010). O’Brien dan Kinnaird (1997) menambahkan bahwa komposisi pakan monyet hitam sulawesi di alam ialah 66\% buah-buahan, 2,5\% bagian tumbuhan lainnya, 31,5\% invertebrata. Persentase bagian tumbuhan selain buah sangat tinggi dibandingkan dengan komposisi pakan monyet hitam sulawesi di alam. Pakan invertebrata tidak ada dalam komposisi pakan utama, namun diberikan dalam pakan tambahan berupa ulat. Pakan tambahan berupa telur rebus dan monkey chow juga diberikan untuk memenuhi kebutuhan protein. Selain itu, susu juga diberikan untuk memenuhi kebutuhan protein bagi monyet hitam sulawesi dengan kondisi tertentu, seperti bunting dan habis melahirkan.

Asumsi untuk bahan kebutuhan pakan harian suatu jenis satwa adalah 10\% dari bobot badannya (Anggraini, 2015), maka kebutuhan pakan untuk individu dewasa monyet hitam sulawesi dengan asumsi berat badan $11 \mathrm{~kg}$ adalah sebanyak $1,1 \mathrm{~kg}$ per hari (asumsi berat badan individu dewasa diambil dari berat rata-rata menurut Suprijatna dan Wahyono, 2000). Asumsi berat badan anak ialah 1/3 dari individu dewasa, sehingga asumsi kebutuhan pakan untuk anak ialah 0,4 kg per hari. Berdasarkan asumsi tersebut, maka jumlah pakan yang dibutuhkan untuk monyet hitam sulawesi di kandang A dengan individu dewasa sebanyak 3 ekor dan anak sebanyak 2 ekor ialah 4,1 kg per hari. Jumlah pakan pakan yang diberikan untuk monyet hitam sulawesi di kandang A sebanyak rata-rata 4,6 kg per hari. Jumlah ini dinilai sudah memenuhi kebutuhan minimum pakan monyet hitam sulawesi di kandang A. Jumlah pakan yang dibutuhkan untuk monyet hitam sulawesi di kandang B dengan 2 individu dewasa ialah 2,2 kg. Jumlah 
pakanyang diberikan untuk monyet hitam sulawesi di kandang B sebanyak 2,6 kg per hari. Jumlah ini juga dapat dinilai sudah memenuhi kebutuhan minimum pakan monyet hitam sulawesi di kandang B.

Menurut Dirjen PHKA (2011), pakan bagi satwa harus memenuhi beberapa syarat, antara lain: pakan harus bersih, segar, dan bebas dari kontaminasi, cocok dan sesuai selera satwa, tidak menimbulkan gangguan metabolisme, dalam jumlah yang cukup, mutu baik, seimbang dan bervariasi. Pakan untuk monyet hitam sulawesi disimpan dalam ruangan khusus berpendingin ruangan dan freezer untuk menjaga kualitas pakan agar tetap segar saat diberikan. Jika ditemukan pakan dalam kondisi yang kurang baik, misalnya busuk akan dibuang dan tidak diberikan kepada satwa.

Air yang disediakan di PPS untuk monyet hitam sulawesi adalah air tanah yang telah difilter terlebih dahulu dan ditampung dalam tempat penampungan air. Tempat minum didalam kandang peraga berupa kolam permanen. Ketersediaan air dalam kolam tersebut selalu dipantau oleh perawat hewan, sehingga air untuk minum monyet hitam sulawesi selalu tersedia. Namun, kebersihan kolam masih kurang terjaga. Masih tampak kontaminasi kotoran dalam kolam, dan pembersihan kolam dilakukan dengan rentang waktu tidak menentu.

Pemberian pakan monyet hitam sulawesi di PPS dilakukan oleh perawat satwa (animal keeper). Pakan yang diberikan sebelumnya telah dipotong kecil-kecil oleh dan dicampur dalam sebuah wadah (nampan). Hal ini dilakukan untuk memudahkan dalam pemberian dan pengaturan makanan, serta memudahkan agar semua individu monyet hitam sulawesi mendapatkan semua jenis pakan yang diberikan. Pakan utama diberikan pada pukul 08.30 WIB. Pemberian pakan utama dilakukan dengan memindahkan satwa kedalam kandang tidur, kemudian perawat akan masuk kedalam kandang peraga untuk meletakan pakan pada tempat pakan yang tersedia.

Pemberian pakan tambahan dilakukan pada pukul 13.00 WIB oleh perawat satwa. Cara pemberian pakan tambahan ini cukup berbeda dengan pakan utama. Setelah pakan dipotong kecil-kecil, pakan diberikan langsung kepada masing-masing individu satwa oleh perawat melalui lubang-lubang pada kawat pembatas kandang. Cara ini dimaksudkan agar satwa dapat mendekat kepada perawat, sehingga perawat dapat memeriksa kondisi satwa secara langsung.

\section{Aspek Bebas dari Rasa Ketidaknyaman Suhu dan Fisik}

Berdasarkan hasil pengamatan, dapat diketahui bahwa kandang monyet hitam sulawesi di PPS terdiri dari dua jenis kandang yaitu kandang tidur dan kandang peraga. Kandang peraga merupakan kandang dengan konsep terbuka, sedangkan kandang tidur merupakan kandang tertutup. Kandang peraga A berukuran $\pm 300 \mathrm{~m}^{2}$ dan kandang peraga $B$ berukuran $\pm 48 \mathrm{~m}^{2}$. Kandang tidur A terdiri dari tiga sel kandang perawatan yang menyatu yang berukuran 12,5 $\mathrm{m}^{2}$ dengan tinggi 2,5 m. Sedangkan kandang tidur B berukuran 7,5 $\mathrm{m}^{2}$ dengan tinggi 2,5 m.

Menurut dirjen PHKA (2011) syarat minimum kandang dalam pengelolaan dan perawatan satwa yaitu luas kandang harus cukup untuk satwa bergerak secara bebas, harus ada enhrichment, kontruksi kandang harus kuat sehingga tidak membahayakan satwa, terdapat tempat untuk berlindung satwa, ketersediaan udara yang segar dan ketersediaan kualitas air. Semua kandang monyet hitam sulasesi di PPS sudah memenuhi syarat luas minimum kandang. Walaupun jika dibandingkan dengan wilayah jelajah (homerange) dari monyet hitam sulawesi di habitat aslinya, yaitu 59 ha masih jauh berbeda (Saroyo, 2004).

Suhu kandang merupakan salah satu aspek penting yang terkait rasa nyaman satwa (Anggraini, 2015). Berdasarkan hasil pengukuran suhu harian di kandang A dan kandang B, suhu harian di kandang B lebih rendah dibandingkan dengan suhu harian di kandang A. Hal ini karena kandang B ternaung oleh tanaman hidup, sehingga suhu di sekitar kandang B menjadi lebih sejuk. Menurut O'brien dan kinnard (1997) suhu minimum dan maksimum 
di habitat asli monyet hitam sulawesi ialah $21,7-23,9^{\circ} \mathrm{C}$ dan $29,2-34,4^{\circ} \mathrm{C}$. Suhu dapat berpengaruh terhadap aktivitas monyet hitam sulawesi di dalam kandang, karena pada saat suhu panas monyet hitam sulawesi cenderung diam atau tidak banyak melakukan aktivitas. Menurut Yani et al. (2007) faktor-faktor yang dapat mempengaruhi suhu di dalam kandang diantaranya adalah radiasi sinar matahari yang masuk ke dalam kandang, produksi panas oleh tubuh satwa dan kondisi konstruksi kandang.

Ventilasi merupakan sarana pertukaran udara segar ke dalam kandang dan pengeluaran udara kotor dari kandang ke ruang terbuka. Ventilasi pada kandang peraga monyet hitam sulawesi di PPS berupa dinding pembatas yang sebagian besar tersusun atas kawat. Sedangkan ventilasi pada kandang tidur berupa jendela berukuran 0,5x0,5 $m$ dengan jeruji besi. Penerangan pada kandang monyet hitam sulawesi kurang memadai saat malam hari, karena tidak ada lampu di dalam kandang, penerangan yang tersedia ialah dari lampu jalan disekitar kandang.

Shelter/cover merupakan tempat berlindung yang penting untuk satwa. Menurut Bolen dan Robinson (2003) shelter/cover berfungsi sebagai pencegah pengeluaran energi yang berlebihan pada satwa, tempat berlindung satwa dari cuaca buruk, dan predator. Hakim (2010) menambahkan bahwa monyet hitam sulawesi di alam memanfaatkan struktur vegetasi yang ada sebagai cover. Kandang peraga A tidak dilengkapi shelter/cover khusus, monyet dalam kandang A biasanya memanfaatkan bayangan dari dinding batu untuk berteduh saat hari sedang terik. Sedangkan kandang B memiliki cover vegetasi dari tumbuhan merambat yang tumbuh dibagian atas kandang peraga dan pohonpohon besar di sekitar kandang.

\section{Aspek Bebas dari Rasa Sakit, Luka dan Penyakit}

Berdasarkan hasil pengamatan diketahui tidak ada tanda-tanda monyet hitam sulawesi yang sakit. Selama waktu penelitian, hanya ada satu individu monyet hitam sulawesi yang mengalami infeksi jamur pada bagian tangannya. Berdasarkan hasil wawancara dengan perawat satwa, diketahui bahwa penyakit yang pernah diderita oleh monyet hitam sulawesi adalah diare, infeksi jamur, dan luka akibat perkelahian.

Pemeriksaan kesehatan monyet hitam sulawesi di PPS dilakukan oleh perawat satwa setiap hari. Pemeriksaan dilakukan dengan mengamati perilaku dan melihat kotoran monyet hitam sulawesi. Tidak ada pemeriksaan rutin yang dilakukan oleh dokter hewan. Pemeriksaan kesehatan oleh dokter hewan dilakukan berdasarkan laporan perawat satwa. Apabila ada satwa yang sakit, maka perawat akan melaporkan ke dokter hewan, setelah itu dokter hewan akan memeriksa kondisi satwa.

Tindakan pencegahan penyakit sekaligus untuk meningkatkan daya tahan tubuh monyet hitam sulawesi di PPS dilakukan dengan memberikan multivitamin dan mineral. Vitamin dan mineral yang diberikan yaitu sakatonik $\mathrm{ABC}$ dan becombion yang diberikan satu bulan sekali. Pencegahan cacingan dilakukan dengan pemberian obat cacing setiap enam bulan sekali.

\section{Aspek Bebas Berperilaku Alami}

Berdasarkan hasil pengamatan, tidak ada individu monyet hitam sulawesi yang menunjukan perilaku stereotipe. Menurut ISAW (2013), berbagai perilaku stereoptipe pada hewan ialah swaying, bar biting, pacing, apathy, dan rocking. Namun, monyet hitam sulawesi PPS telah terhabituasi dengan kehadiran pengunjung. Namun, masih banyak ditemukan adanya perilaku agonistik terhadap kehadiran pengunjung yang mengusik monyet hitam sulawesi, seperti dengan berteriak dan menakut-nakuti monyet hitam sulawesi. Hal ini dilakukan monyet hitam sulawesi untuk mempertahankan diri dan wilayah teritorinya.

Pengayaan kandang (enrichment) diperlukan untuk mendukung monyet hitam sulawesi berperilaku seperti 
di habitat alaminya. Menurut Manangsang (2012), kandang seharusnya tidak hanya ditujukan untuk menjaga satwa agar tidak lepas dan membatasi pengunjung, tetapi harus sesuai dengan kebutuhan hidup, tingkah laku dan habitat satwa. Posta et al. (2013) menambahkan bahwa fasilitas pada kandang terbuka dapat dilakukan dengan membuat pengayaan berupa substrat pasir pada lantai kandang, kolam yang cukup dalam, adanya pepohonan, dan berbagai tumpukan batang kayu. Kandang peraga A dilengkapi dengan batu buatan, batang pohon mati, pohon dan ranting buatan sebagai untuk istirahat, melakukan aktivitas sosial dan juga merupakan tempat pakan monyet hitam sulawesi. Kolam air sebagai tempat penayedia air minum. Tali yang terbuat dari karet dan bola yang digantung sebagai sarana bergerak dan bermain, serta rumput yang melapisi lantai kandang dapat menjadi sumber pakan tambahan. Kandang peraga B dilengkapi dengan pohon dan ranting buatan, kolam, tali dari karet, substrat tanah berpasir, tanaman merambat pada atap kandang yang berfungsi sebagai cover dan tanaman jambu yang tumbuh dari sisa pakan yang diberikan. Selain itu kandang peraga B juga dilengkapi pagar pembatas besi untuk membatasi jarak antara pengunjung dengan satwa.

\section{Aspek Bebas dari Rasa Takut dan Menderita}

Secara umum, kondisi monyet hitam sulawesi di PPS saat penelitian berlangsung ialah baik. Tidak terlihat adanya individu satwa yang mengalami rasa takut, menderita maupun stres. Jordan (2005) menyatakan stres pada satwa dapat terjadi saat satwa mengalami kondisi fisik dan emosi yang terganggu.

Tindakan pencegahan yang dilakukan untuk menghindari satwa dari rasa takut, menderita ataupun stres ialah dengan melakukan pengamatan dan pemantauan rutin oleh perawat hewan, sehingga jika satwa menunjukan perilaku yang tidak normal akan cepat diketahui dan dilakukan penanganan. Sedangkan penanganan yang dilakukan apabila ada satwa yang stres ialah dengan memberikan vitamin bila satwa tidak nafsu makan, pendekatan oleh perawat hewan, serta memasukan satwa kedalam kandang perawatan jika diperlukan untuk menghindarkan satwa sementara dari pengunjung.

\section{KESIMPULAN}

Kesimpulan dalam penelitian ini adalah:

1. Perilaku harian monyet hitam sulawesi berbeda berdasarkan jenis kelamin, yaitu pada perilaku bergerak, mencari makan, istirahat dan sosial.

2. Perilaku harian monyet hitam sulawesi berbeda berdasarkan umur, yaitu pada perilaku bergerak, mencari makan, istirahat dan sosial.

3. Tingkat kesejahteraan monyet hitam sulawesi di PPS termasuk dalam kriteria baik.

\section{DAFTAR PUSTAKA}

Anggraini H. 2015. Pengelolaan Kesejahteraan dan Aktivitas Harian Orang Utan Kalimantan (Pongo pymeus) di Pusat Primata Schmutzer. Skripsi. Institut Pertanian Bogor. Bogor.

Asteria, Yuriestia A., Raharjo L., Sjahfirdi L., Adil E.I.M., Maheswari H., Astuti P. 2008. Aktivitas Harian Yaki (Macaca nigra) di Penangkaran Selama Periode Esterus dan Anesterus. Proceeding seminar nasional biodiversitas II. Surabaya. hlm. 227-229.

Biro, P.A dan stamps, J.A. 2010. Do consistent individual differences in metabolic rate promote consistent individual 
differences in behavior. Trends in Ecology and Evolution Vol.25 No.11

Cawthon, L.K.A. 2006. Primate Factsheets: Crested black macaque (Macaca nigra) Taxonomy, Morphology, and Ecology. www. pin.primate.wisc.edu [17 Maret 2016]

[FAWC] Farm Animal Welfare Council. 2009. Five Freedoms. http://www.fawc.org.uk/freedoms.htm [14 Maret 2016]

Fragaszy, D. M., and Boinski, S. (1995) Patterns of individual diet choice and efficiency of foraging in wedge-capped capuchin monkeys (Cebus olivaceus). J. Comp. Psychol. 109:1-10.

Hakim S.S. 2010. Karakteristik Habitat dan Populasi Monyet Hitam Sulawesi (Macaca nigra Desmarest, 1822) pada Beberapa Tipe Habitat di Cagar Alam Tangkoko, Sulawesi Utara. Skripsi. Institut Pertanian Bogor. Bogor.

[ISAW] Indonesian Society of Animal Welfare. 2013. Prinsip Kesejahteraan Satwa di Kebun Binatang. http://www.isaw.or.id [20 Maret 2016] Katili D. dan Saroyo. 2011. Perbandingan Aktivitas Harian Dua Kelompok Monyet Hitam Sulawesi (Macaca Nigra) di Cagar Alam Tangkoko-Batuangus, Sulawesi Utara. Jurnal Ilmiah Sains 11(2) : 161-165.

Jordan, B. 2005. Science based Assessment Of Animal Welfare: Wild And Captive Animals. Rev. sci. tech. Off. int. Epiz. 24 (2): 515-528.

Kartono P.A, Prastyono, Maryanto I. 2002. Variasi Aktivitas Harian (Hylobates moloch Audebert, 1798) Menurut Kelas Umur Di Tn Gunung Halimun, Jawa Barat. Berila Biologi, Volume 6. Nomor A April 2002, Edisi Khusus “Biodiversitas Taman Nasional Gunung Halimun (II) “.

Kyes R.C., Iskandar E., Onibala J., Paputungan U., Laatung S., Huettmann F. 2012. Long-term population survey of the sulawesi black macaques (Macaca nigra) at Tangkoko Nature Reserve, North Sulawesi, Indonesia. American Journal of Primatology 75(1) : 1-7.

Lazzer et.al. 2010. Relationship between basal metabolic rate, gender, age, and body composition in white obese subjects. Obesity Silver Spring 18(1):71-8.

Martin P. dan Bateson P. 1993. Measuring Behaviour: An Introduction Guide $2^{\text {nd }}$ Ed. Cambridge University Press. New York.

Melfi V.A dan Feitsner A.T.C. 2002. A Comparison of the Activity Budgets of Wild and Captive Sulawesi Crested Black Macaques (Macaca nigra). Animal welfare 11:213-222.

National Institute of Health. 1985. Guide for The Care and Use of Laboratory Animals. DHEW Publ No (NIH) 85-23, pp.1-83. Committee on Care and Use of Laboratory Animals of The Insitute of Laboratory Animal Resources, U.S. Dept of Health and Human Services, Public Healt Services. National Institute of Health, Bethesda, M D.

O’Brien T.G. dan Kinnaird M.F. 1997. Behavior, Diet and Movements of the Sulawesi Crested Black Macaque. International Journal of Primatology 18(3): 321-351.

Paputungan U., Kyes R.C., Adiani S., Daniel J., Rembet D., Poluan C., Yusuf T.L., dan Sajuthi D., 2000. Siklus Menstruasi Monyet Hitam Sulawesi (Macaca nigra). Jurnal Primatologi Indonesia 3: 2-8.

Pasetha A. 2014. Perilaku Harian Monyet Hitam Sulawesi (Macaca nigra) pada Masa Kebuntingan di Cagar Alam TangkokoBatuangus, Sulawesi Utara. Skipsi. Institut Pertanian Bogor. Bogor.

[PKBSI] Perhimpunan Kebun Binatang Se-Indonesia. 2000. Pengelolaan Taman Satwa di Indonesia. Jakarta (ID): PKBSI.

Prayogo, H. 2006. Kajian Tingkah Laku dan Analisis Pakan Lutung Perak (Trachypitecus cristatus) di Pusat Primata Schmutzer Taman Margasatwa Ragunan. Tesis. Institut Pertanian Bogor. Bogor.

Posta B, Huber R, Moore III DE. 2013. The Effects of Housing on Zoo Elephant Bahavior: A Quantitative Case Study of Diurnal 
and Seasonal Variation. International Journal of Comparative Psychology (26): 37-52.

Republik Indonesia. 2011. Peraturan Direktur Jenderal Perlindungan Hutan dan Konservasi Alam Nomor : P. 6/IV-SET/2011 Tentang Pedoman Penilaian Lembaga Konservasi. Sekretariat Negara. Jakarta.

Saroyo. 2005. Karakteristik Dominansi Monyet Hitam Sulawesi (Macaca nigra) di Cagar Alam Tangkoko-Batuangus Sulawesi Utara. Tesis. Sekolah Pasca Sarjana IPB. Bogor.

Saroyo. Mansjoer S.S, Tarumingkeng R.C, Solihin D.D, Wanatabe K. 2006. Aktivitas Harian Monyet Hitam Sulawesi (Macaca nigra) di Cagar Alam Tangkoko-Batuangus, Sulawesi Utara. Biosfera 23 (1)

Saputra K.G.W, Watiniasih N.I, Ginantra I.K. 2012. aktivitas harian kera ekor panjang (macaca fascicularis) di taman wisata alam sangeh, kabupaten badung, bali. jurnal biologi xviii (1) : 14 - 18. Universitas Udayana. Bali

Supriatna J. dan Wahyono E.H. 2000. Panduan Lapangan Primata Indonesia. Yayasan Pustaka Obor Indonesia. Jakarta.

Supriatna J. dan Andayani N. 2008. Macaca nigra IUCN Red List of Threatened Species. www.iucnredlist.org [5 Maret 2016]

Widyanyandani W.W. 2010. Kesejahteraan Hewan bagi Kesehatan Manusia. http://www.profauna.org [12 Maret 2016] 